\title{
JEJAK CLIFFORD GEERTZ DI INDONESIA: MENGOREKSI TRIKOTOMI SANTRI,ABANGAN DAN PRIYAYI
}

\section{A. Khoirul Anam \\ Peneliti Islam Nusantara, Dosen Syari'ah STAINU Jakarta}

\section{PENDAHULUAN}

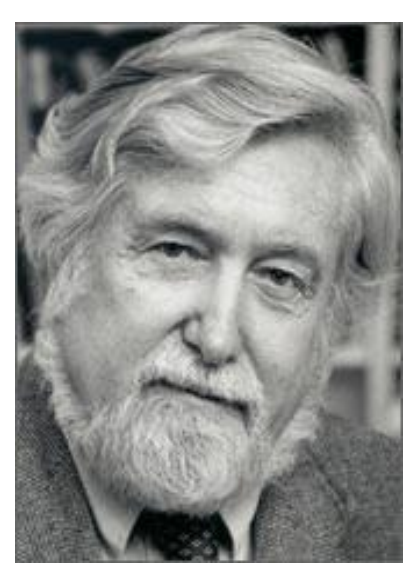

Yang membuat Clifford Geertz populer di Indonesia adalah tesisnya tentang trikotomi santri, abangan, dan priyayi, hasil penelitiannya atas agama-agama di Jawa. Trikotomi ini telah dikritik sana-sini, namun sebagai sebuah penelitian anthropologis dengan model pengkajiannya yang unik tesis Geertz tetap menarik sebagai bahan kajian, bahkan kadang dikutip secara "apa adanya" oleh para pengkaji agama dan anthopologi budaya di Indonesia.

Selain membuka kembali hasil penelitian Geertz tentang agama-agama di Jawa, ditambah penelitiannya tentang Bali, tulisan ini akan mengkaji lebih jauh seputar gaya antropologi budaya yang dikembangkannya. Geertz adalah pengikut setia Max Weber dalam hal menempatkan agama sebagai acuan utama untuk bersinggungan dan mengenal "segerombolan" masyarakat primitif seperti Jawa. Namun berbeda dengan Weber yang menjadikan kemunduran perekonomian sebagai “kemunduran” beragama, dalam bukunya Agriculture Involution (1963) Geertz menyimpulkan bahwa kemunduran pertanian di Indonesia bukan sebab agama yang salah asuhan; ada hal lain yang menyebabkan perokonomian Indonesia tidak bersemangat dan jalan di tempat (mengalami involusi).

Tulisan ini hanya mengkaji analisis Geertz tentang agama hubungannya dengan aspek kebudayaan secara umum, dengan tetap berpijak pada Weber. Jika Weber mengaitkan antara agama dengan spirit ekonomi, sebaliknya, Geertz memakai analisis kelas ekonomi untuk membuat(-buat) semacam “aliran” keagamaan di Jawa, seperti dalam trikotomi di atas. Lebih jauh, sebagai seorang anthropolog budaya Geertz menggunakan ritual-ritual dan kepercayaan terhadap agama dalam kelompok 
masyarakat yang ditelitinya sebagai acuan utama untuk mendapatkan suatu kesimpulan anthropologis yang kadang terlalu berani.

Ciri utama anthropologi Geertz adalah keinginannya yang kuat untuk dapat memberikan pemaknaan yang mendalam terhadap fenomena budaya yang ditelitinya. Ada yang khas, Geertz tidak pernah asik dengan penjelasan yang menurutnya samar. Kebudayaan, harus dideskripsikan sejelas-jelasnya dengan cara "memaknai" tindakan orang-orang yang, menurutnya, diatur oleh sebuah "ide" yang disepakati bersama. Tidak sekedar ingin menjelaskan fenomena budaya, dalam penelitiannya di Bali Geertz mencoba menerapkan konsepnya untuk menyusun sejarah Bali dengan menyusun datadata, entah berupa mitos atau catatan peristiwa sejarah, dengan cara membubuhkan jalinan-jalinan makna.

\section{BERANGKAT DARI TEORI WEBER}

Clifford Geertz lahir di San Fransisco, California, tahun 1926. Setelah menyelesaikan pendidikan menengahnya, ia memasuki Antioch College Ohio dan pada tahun 1950 dia memperoleh gelar B.A. pada bidang filsafat. Geertz melanjutkan studinya pada bidang anthropologi di Harvard University. Di sini Geertz berada di bawah bimbingan teoritisi terkemuka, Talcott Parsons .

Talcott Parsons adalah ${ }^{1}$ orang yang paling berjasa dalam menyosialisasikan gagasan sosiolog besar asal Jerman, Max Weber. Dia menerjemahkan beberapa karya Weber dan menjelaskan ide- ide pokoknya kepada orang-orang Amerika. Melalui Parson, orang-orang tahu Weber-lah orang pertama yang menghubungkan Protestantisme dengan ekonomi kapitalis dalam esai-isainya yang terkumpul dalam The Protestan Etic and Spirit of Kapitalism (1904/1905). Selanjutnya Weber memperluas kajiannya pada agama agama besar di dunia seperti Islam, Yahudi, Katholik, Hindu, Budha, sampai Konfusianisme. Semuanya dihubungkan dengan kapitalisme. Berangkat dari Weber, Geertz kelak memakai agama dan berbagai aspeknya sebagai alat utama untuk memahami budaya masyarakat yang ditelitinya.

Hal terpenting yang diambil Geertz dari Weber adalah metodenya yang banyak diperbincangkan orang, verstehen (kata jerman untuk “memahami’ atau understanding)

\footnotetext{
${ }^{1}$ Daniel L. Pals, Seven Theoris of Religion (STR) (Dari Animisme Karl Marx Hingga Anthropologi Budaya C. Geertz), terj. Qalam, Yogyakarta: 2001, hla. 401. Riwayat Geertz selanjutnya diperoleh dari buku ini.
} 
yang menekankan peran ide dan sikap manusia dalam menjelaskan sistem sosial. Bahwa kebudayaan adalah produk tindakan manusia; kebudayaan ada karena manusia melakukan hal-hal yang sesuai dengan ideal, sikap, dan nilai. Geertz kelak melanjutkan metode Weber ini dengan memahami arti (interpretasi) tindakan masyarakat yang ditelitinya; untuk menangkap dan menjelaskan apa sebenarnya yang sedang berlangsung. Dari seluruh esai-esainya yang teoritis kelak, memang, tak seorang pun yang sering dirujuk Geertz selain Weber.

Selama tahun kedua di Harvard, ia dan istrinya Hildred Geertz pergi ke pulau Jawa untuk meneliti sebuah kota kecil di Jawa Timur yang multi agama dan multiras. Setelah kembali ke Harvard, Geertz memperoleh gelar doktor dari Harvard's Departement of Social relation dengan spesialisasi dalam bidang anthropologi. Bersama istrinya ia kemudian berangkat untuk melakukan kerja lapangan untuk kedua kalinya di Indonesia. Kali ini dia pergi ke Bali.

Geertz berada dalam tradisi anthropologi profesional yang dikembangkan di Amerika Serikat di bawah kepemimpinan imigran asal Jerman Franz Boas (18831957), Alfred Luis Krober (1876-1960) dan Robert Lowie (1883-1957). Para anthropolog Amerika sedang mengembangkan metode anthropologi sendiri yang diklaim berbeda dengan Inggris dan Perancis. Para tokoh perintis ini menegaskan bahwa setiap teori anthropologi harus berasal dari etnografi partikular yang diteliti, berpusat pada suatu komunitas yang diteliti selama bertahun-tahun Tidak hanya masyarakatnya, tetepi juga ide, adat istiadat, sikap, simbol, dan institusi.

Masyarakat menurut antropolog Amerika adalah suatu istilah yang ditekankan pada komponen komunitas manusia yang bersifat struktural dan material semata, sedang istilah yang lebih tepat untuk memahami konsep masyarakat secara lebih menyeluruh, meneliti sikap dan emosi yang tersembunyi di balik tatanan masyarakat, adalah budaya (culture). Jika orang-orang eropa memakai istilah "masyarakat" (society) dan "anthropologi masyarakat" (social anthropology), para anthropolog Amerika ini lebih senang memakai istilah "budaya" (culture) dan anthropologi budaya (cultural anthropology). Antropolog Amerika lebih senang mengamati dan memberikan penafsiran atas hal-hal yang berada di balik realitas yang tampak. Geertz berada dalam tradisi ini, dan ditambah gagasan-gagasan Weber yang diperolehnya dari Parsons, dia lebih kreatif dalam mengembangkan tradisi Anthropologi Amerika. 
Pada tahun 1958, setelah menyelesaikan kerja lapangannya di Bali, Geertz secara sejenak menjadi anggota staf pengajar di Universitas California di Berkeley; ia kemudian pindah ke University of Chicago selama sepuluh tahun, dari tahun 1960 sampai tahun 1970. Pada tahun 1960, ia menerbitkan buku berjudul The Religion of Java, sebuah catatan hasil penelitiannya yang pertama di Indonesia.

Di samping karyanya tentang agama, Geertz juga meneruskan penelitian yang menghasilkan beberapa buku. Agriculture Involution (1963) meneliti ekologi dan ekonomi Indonesia dan memperkirakan kesulitan dan prospeknya di era pascakolonial. Peddlers and Princes diterbitkannya pada tahun yang sama, membandingkan kehidupan ekonomi suatu kota kecil di Jawa dengan Bali. The Social History an Indonesian Town (1965) menceritakan kisah komunitas tempat Geertz melakukan sebagian besar kerja lapangannya yakni Mojokuto di Jawa Timur dengan memperhatikan hubungan yang dekat antara ekonomi, politik dan kehidupan sosial ketika komunitas itu bergerak daripemerintahan kolonial ke kemerdekaan.

Geertz lalu beranjak ke Maroko melakukan perjalanan ke lima wilayah di sana untuk mengamati sebuah komunitas agama kaum Muslim yang kedua di dalam bagian dunia yang betul-betul berbeda dari Asia tenggara. Sebagai hasilnya, di dalam Islam Observed (1968) ia dapat membuat studi perbandingan tentang suatu agama besar, Islam, ketika agama itu mengambil bentuk di dalam dua latar belakang kebudayaan yang betul-betul berbeda. Tahun-tahun selanjutnya, kerja lapangan di Afrika utara ini membawa lebih lanjut pada studi, Meaning and Order Moroccan Society (1980), hasil sumbangan dari Geertz dan para penulis yang lain.

Pada 1970, Geertz menjadi satu-satunya anthropolog yang pernah disebut professor di sebuah lembaga terkenal, tempat Albert Einstin bekerja, Institut for Advances Study di Princeton, New Jersey sekaligus sebagai markas penelitiannya yang baru. Kehormatan tunggal ini bukan karena laporan hasil penelitiannya, namun karena banyak orang Amerika yang dari berbagai bidang ilmu pengetahuan yang terpesona dengan serangkaian esai- esainya yang kritis, yang membicarakan berbagai isu teoritis yang penting dalam lapangan anthropologi modern. Ia dapat membuat suatu argumen yang memaksa tentang gaya anthropologi "interpretatifnya” yang lebih baru.

Esai-esai Geertz yang paling ramai dibincang adalah koleksinya yang berjudul The Interpretation of Culture (1973) dan Local Knowledge (1983). Geertz menawarkan 
sebuah solusi, katakanlah sebuah terobosan agar konsep kebudayaan yang meliputi nilai, simbol, kepercayaan, dan lainnya yang rumit itu tidak lagi samar; bisa dijelaskan lebih kongkret dan obyektif. Pada sub bab berikut, tulisan ini akan mengkaji sejauh mana terobosan- trobosan Geertz itu yang ternyata diperolehnya dari Talcott Parsons yang dikembangkan dari gagasan induk Weber. Juga bagaimana Geertz menerapkannya di Jawa dan Bali.

\section{MEMAKNAI BUDAYA SECARA MENDALAM}

Sebagai pengantar untuk kumpulan tulisan-tulisannya yang sebelumnya telah ditulisnya dalam jurnal-jurnal ilmiah, Geertz menulis sebuah esai baru yang berjudul Thick Diskription: Toward an Interpretative Theory of Culture (Deskripsi Mendalam: Menuju suatu teori kebudayaan yang interpretatif). Pertama-tama ia menegaskan bahwa meskipun istilah "budaya" cenderung multitafsir, namun ciri kunci dari kata itu adalah "makna" dan "signifikansi". Manusia, kata Geertz, mengutip Max Weber, adalah seekor binatang yang tergantung dalam jaringan makna yang dia bentangkan sendiri. Untuk menjelaskan kebudayaan manusia lain, kata Geertz, tidak ada pilihan lain kecuali dengan melakukan diskripsi mendalam. Tujuan teori adalah untuk menjelaskan sesuatu tentang manusia bukan menjelaskan sesuatu yang kabur².

Istilah diskripsi mendalam (thick diskription) itu diperoleh Geertz dari seorang anthropolog Inggris Gibbert Ryle yang memberikan contoh mengenai gerakan mata dua anak laki- laki yang berbeda. Satu di antaranya mengalami kedutan mata secara tidak disengaja, sedang yang lain mengerdipkan matanya kepada temannya. Dalam penjelasan yang secara fisik semata, dua gerakan mata ini tampak sama. Tetapi jika kita memperhatikan unsur makna dan signifikansi, dua gerakan itu tidak akan sama lagi. Yang satu tidak memiliki arti apa-apa, sementara yang lain multimakna ${ }^{3}$.

Geertz mengatakan, analisis budaya bukanlah sebuah sains eksperimental yang mencari sebuah kaidah, tetapi sebuah sains interpretatif yang mencari makna. Bahwa makna ini bukanlah sesuatu yang sifatnya pribadi atau berada di kepala individu. Ketika seseorang memahami kerdipan mata temannya maka ada sesuatu yang memang bersifat umum katakanlah sebuah komputer yang terprogram yang difahami bersama

\footnotetext{
${ }^{2}$ Clifford Geertz, The Interpretation of Cultures: Selected Assays (IC), diterjemahkan oleh Fransisco Budi Hardiman, Kanisisus, Yogyakarta: 1992, hlm. 4

${ }^{3} \mathrm{IC}$, hlm. 6
} 
oleh "kita berdua". "Kita tidak boleh hanya mengambarkan apa yang sebenarnya terjadi tetapi apa yang dimaksudkan orang dengan apa yang terjadi," demikian Gibbert Ryle, seperti dikutip Geertz ${ }^{4}$. Tugas para anthropolog, kata Geertz adalah menjelaskan makna bersama ini, yang diperoleh dan berasal dari orang-orang lain pada saat anthropolog membaurkan diri bersama masyarakat yang ditelitinya. Menarik menyimak, Geertz dalam trikotominya nanti mengenai agama di Jawa yang menurutnya adalah atas pengakuan orang Jawa sendiri.

Dalam pandangan Amerika, orang cenderung menegaskan bahwa prilaku individuadalah suatuekspresidaribudaya, sementara budaya didefinisikan semata-mata sebagai suatu cara individu berperilaku. Hal ini masih samar dan kelak Geertz memperoleh jawabannya dari Parsons. Dalam bukunya yeng terpenting, The Structure of Social Action (1934), Parsons bersandar pada Weber bahwa semua kelompok manusia berada pada tingkat organisasi: (1) keperibadian individual yang dibentuk dan diatur oleh, (2) suatu sistem sosial, yang dibentuk dan dikontrol oleh, (3) suatu sistem budaya yang terpisah. Yang terakhir ini merupakan suatu jaringan yang komplek dari nilai, simbol, dan kepercayaan yang berinteraksi dengan individu dan masyarakat, tetapi untuk tujuan analisis ia dapat dipisahkan dari kedua hal sebelumnya $^{5}$. Singkatnya, Weber telah menunjukkan bagaimana memahami suatu budaya, Parsons telah menunjukkan tempat untuk menemukannya, sementara Geertz telah mempraksiskannya.

Namun demikian, Geertz melanjutkan, suatu kebudayaan bukan hanya tentang makna, seolah-olah ia adalah sistem simbol yang dapat berdiri sendiri seperti halnya matematika. Perilaku atau tindakan atau lebih tepatnya tindakan sosial juga harus diamati, karena melalui pengamatan prilakulah kebudayaan menemukan artikulasi. Orang-orang kadang berperilaku dalam cara-cara yang tampak berbenturan dengan sistem makna yang diterapkan oleh kebudayaan mereka sendiri. Geertz tidak segansegan mengatakan bahwa ada kepura-puraan di sini. Dengan begini diskripsi seorang anthropolog tidak selamanya harus konsisten. Analisis budaya selalu merupakan masalah menduga-duga makna, mengira-ngira dugaan, dan menarik kesimpulan penjelasan.

\footnotetext{
${ }^{4}$ STR, 408

${ }^{5}$ STR, hlm. 412
} 
Geertz menegaskan bahwa kegiatan budaya manusia merupakan hal yang luar biasa dan sangat khas dan karena itu kita tidak akan ke mana-mana jika kita mencoba "menjelaskan" semua itu menurut cara penjelasan saintis dalam dunia natural. Suka atau tidak suka, makhluk manusia berbeda dengan atom dan serangga. Manusia hidup dalam suatu sistem makna yang ruwet, yang disebut oleh para anthopolog dengan "budaya-budaya". Anthropologi tidak sepenuhnya bersifat prediktif, tidak pernah dapat memberikan kepastian seperti yang ada dalam bidang- bidang kimia dan fisika. Seorang anthropolog tidak dapat berkata dengan pasti apa yang akan terjadi dalam suatu kebudayaan, bukan seorang dokter yang dapat memprediksi secara optimis bahwa seorang anak akan terkena penyakit cacar.

Maka temuan-temuan anthropologis pada waktunya tidak akan memberikan penjelasan apa-apa, yakni ketika tanda-tanda lama tidak lagi menjelaskan apa-apa kepada kita. Inilah sepertinya yang hendak disampaikan Geertz dengan berat hati di akhir- akhir hayatnya dalam After The Fact (1995); kejadian dahulu, perumusan kemudian ${ }^{6}$.

\section{MENJADIKAN AGAMA SEBAGAI MEDAN ANTHROPOLOGIS}

The Religion of Java yang merupakan hasil penelitiannya pertama Geertz diangap sebagai sebuah karya anthropoligi gaya Amerika yang terbaik. Namun buku itu tidak mencoba mengatakan suatu sifat teoritis tentang tujuan pendekatan interpretatifnya terhadap agama. Geertz menunjukkan pendekatan interpretatifnya dalam esainya Religion as a Cultural Sistem yang pertama kali baru diterbitkan pada 1966 den kemudian dimasukkan dalam the Interpretation of Cultures pada 1973.

Geertz pertama-tama menggambarkan kebudayan sebagai "susunan arti”, atau ide, yang dibawa simbol, tempat orang meneruskan pengetahuan mereka tentang kehidupan dan mengekspresikan sikap mereka terhadapnya. Nah, karena dalam suatu kebudayaan terdapat berbagai macam sikap dan berbagai macam bentuk pengetahuan yang diteruskan, maka ada banyak pula " sistem budaya" untuk membawanya: Seni dapat menjadi sistem budaya demikian juga dengan pengetahuan umum, ideologi politik, dan hal-hal yang mempunyai sifat serupa.

\footnotetext{
${ }^{6}$ Lihat Clifford Geertz, After The Fact: Dua Negeri, Empat Dasawarsa, Satu Anthropologi (AF), Terj. L-KiS, Yogyakarta: 1998
} 
Bagaimana dengan agama? Ah, tentu. Geertz mendefinisikan agama sebagai (1) sebuah sistem simbol yang berperan (2) membangun suasana hati dan motivasi yang kuat dan tahan lama di dalam diri manusia dengan cara (3) merumuskan konsepsi hidup yang umum dan (4) membungkus konsepsi ini dengan suatu aura faktualitas semacam itu hingga (5) suasana hati dan motivasi tampak realistik secara unik ${ }^{7}$. Dengan begitu, kata Geertz, maka salah satu yang terpenting dalam memahami budaya adalah agama, dan kita tidak memiliki pilihan kecuali metode yang sesuai dengannya. Metode itu adalah interpretasi. Dalam masalah yang manusiawi, jauh lebih baik jika kita meninggalakan penjelasan prilaku (explanation of behaviors) yang mungkin diterapkan oleh sains natural kepada sekelompok lebah atau jenis ikan, dan sebagai gantinya beralih ke interpretasi budaya.

Ketika dikatakan bahwa simbol-simbol ini membangun suasana hati dan motovasi yang kuat serta tahan lama, maka kita dapat meringkas ini dengan mengatakan bahwa agama membuat orang merasakan sesuatu dan juga ingin melakukan sesuatu. Dengan ini, Geertz mengatakan bahwa agama mau tidak mau telah memberikan penjelasan puncak tentang dunia. Agama menandai suatu wilayah yang memiliki status khusus.

Geertz adalah yang paling serius ingin menunjukkan betapa bernilainya studi agama yang diolah dengan baik guna memahami aspek kehidupan dan pemikiran manusia yang lain. Dia mencoba melihat semua agama melalui mata dan ide orangorang yang mempraktikkannya. Lah, hubungan Geertz dengan komunitas- komunitas di Indonesia telah menjadi sumber dan dorongan dari sebagian besar ide-idenya. Sejak awal hubungan itu telah membawanya pada pandangan bahwa jika agama selalu dibentuk oleh masyarakat, tidaklah kurang benar bahwa sebuah masyarakat telah dibentuk oleh agamanya.

\section{MENDESKRIPSIKAN AGAMA JAWA}

Seperti disinggung di atas, Jawa adalah obyek penelitian professional Geertz yang pertama. Namun buku hasil penelitiannya yang dilakukan selama tiga tahun (1951-1954), The Religion of Java, yang baru diterbikan pada 1960 itu, tidak

\footnotetext{
${ }^{7}$ Clifford Geertz, The Religion of Java (RJ), terj. Santri, Abangan, Priyayi dalam Masyarakat Jawa, Pustaka Jaya, Jakarta: 1981
} 
menyajikan data-data teoritisnya. Buku ini hanya berupa laporan proyek penelitiannya berupa data-data yang didapatnya dari Jawa.

Geertz memokuskan penelitian lapangannya di Mojokuto, sebuah nama samaran untuk salah satu kota kecil di Jawa Timur. Geertz dibantu oleh istrinya tinggal di rumah seorang buruh kereta api di ujung utara kota. Mojokuto adalah sebuah kota kecil di bagian tengah Jawa Timur; kota besar kedua dan daerah pelabuhan utama; terdapat persawahan yang subur; pusat perdagangan, pendidikan dan pemerintahan untuk delapan belas desa di sekitarnya; berpenduduk 20.000 jiwa, terdiri dari 18.000 penduduk asli Jawa, selainnya adalah orang Arab, India dan minorotas lainnya.

Geertz pertama-tama menemukan bahwa ada tiga tipe kelas perekonomian di Jawa (baca Mojokuto), yakni petani dan buruh, pedagang, serta birokrat atau ningrat Jawa. Masing-masing menjalankan tipe kebudayannya sendiri. Selanjutnya, Geertz memokuskan penelitian pada aspek penting dari kebudayaan itu, yakni prilaku keagamaan berupa ritual-ritual dan kepercayaan- kepercayaan yang dijalani masingmasing. Jika Weber memakai etika agama untuk menjelaskan prilaku ekonomi, Geertz memakai pembedaan kelas ekonomi untuk lebih jauh meneliti aspek keagamaan masing-masing kelas. Muncullah penamaan abangan untuk kelas pertama, santri untuk kelas kedua, dan priyayi untuk kelas ketiga. Semuanya ditujukan untuk menjelaskan aspek keagamaan dan bukan lagi ekonomi.

Geertz mencatat, trikotomi itu sekaligus mencerminkan organisasi moral kebudayaan Jawa. Pertama, abangan mewakili suatu titik berat pada aspek animistik dari singkretisme Jawa. Abangan menjalani kepercayaan keagamaan Jawa yang asli, secara luas abangan dihubungkan dengan elemen petani. Kedua, santri mewakili suatu titik berat pada aspek Islam dari singkretisme itu dan terutama dihubungkan dengan elemen dagang. Sementara

Priyayi dihubungkan dengan elemen birokratik. Trikotomi ini, kata Geertz, dikatakan sendiri oleh orang Jawa.

Tipe abangan, kata Geertz, akrab dengan selametan, percaya pada mahluk halus, dan pengobatan dengan mantra dan sihir. Lalu santri adalah yang mematuhi peraturan-peraturan dasar dalam Islam dalam hal ketauhidan, melakoni ritual wajib, dan meninggalkan larangan semisal minuman keras. Namun dalam banyak hal kehidupan santri dan abangan tampak serupa. Perbedaan penting antara santri dan 
abangan adalah bahwa abangan benar-benar terpesona oleh detail keupacaraan. Seorang abangan tahu waktunya kapan harus selamatan, membuat apem atau bubur tanpa harus memberikan tafsiran untuki apa semua itu, sementara santri sangat perhatian terhadap tafsiran moral dan sosial dari doktrin doktrin dan ritual keagamaan yang diyakini.

Santri umumnya merasa tinggi kualitas keagamaannya dibanding abangan. Dalam organisasi sosial, abangan lebih mengutamakan ritual-ritual dalam keluarga dan masyarakat sekitar. Sementara santri merasa bahwa seluruh tanah yang dilejajahinya berada dalam kekuasaan Yang Esa, satu ciptaan; cocok dengan nalar dagang mereka. Priyayi menjalani ritual keagamaan yang sama dengan abangan. Mereka adalah pewaris kebudayaan Jawa yang adiluhung. Istilah wayang, kesenian Jawa, kesusasteraan, birokrasi Jawa semua dikaitkan dengan priyayi ini. Selanjutnya, Belanda memang lebih dominan dalam memperbarat priyayi dan bukan sebaliknya. Priyayi yang ala Baratlah yang paling berkesempatan dalam birokrasi.

Sementara itu dalam perkembangannya, abangan sempat melebur dengan suatu marxisme yang nasionalistik yang mendukung kebijakan politik komunis di Indonesia sambil memurnikan upacara-upacara abangan dari sisa sisa Islam yang terdapat di dalamnya. Peleburan ini semisal orang yang membeberakan rahasia setelah mengucap sumpah setia.mantra terhadap marxisme ini akan sakit, gila, dan mati. Lalu semenjak meruaknya masa pergerakan dan pengumuman tibanya kaum muslimin yang, dikatakan Geertz, telah "sadar diri" dalam cakrawala sosial Indonesia, varian santri menjadi semakin beragam. Salah satunya ketika muncul Muhammadiyah (1912) di Yogyakarta di pusat sekaligus klimak kultur hindu Jawa.

Bagi orang Indonesia asli, paparan Geertz selanjutnya mungkin tidak terlalu menarik. Ketika menjelaskan abangan dia mencatat upacara-upacara, saat menjelsakan santri dia menuliskan kembali sejarah Islam yang dia dapat, sementara priyayi dijelaskannya dengan cara menuliskan kembali sejarah dan khasanah kebudayaan Jawa seperti wayang dan sastra: sebuah paparan tipologis yang tidak konsisten. Para sarjana Indonesia menolak tiga tipe yang diajukan Geertz terkait adanya perbedaan garis temu. Santri dan abangan memang tipe kebudayaan (waktu itu) yang 
lekat dengan prilaku keagamaan. Sementara priyayi terkait dengan organisasi sosial.

Selain soal tipologi yang tidak tepat, kritik lain adalah soal pemahaman geertz terhadap agama. Ada hasil penelitian tandingan yang dilakukan oleh Mark R. Woodward $^{12}$. yang bearanjak dari kesalahan Geetz. Woodward mengatakan bahwa tidak ada abangan di Jawa, yang ada hanyalah Islam yang telah menemukan bentuknya di sana, Islam Jawa. Perbedaan Geertz dengan Woodward adalah hanyalah soal pemahaman agama yang berbeda. Selain memang Geertz merinci penjelasan mengenai santri, seperti disingung di atas, berdasarkan runutan sejarah Islam dari Arab. Yang pasti, jika benar Geertz mengenal agama dari Weber yang menganggap bahwa Islam adalah Timur Tengah, perbedaannya dengan Woodward semakin jelas.

\section{MEMAKNAI BALI}

Kata kunci yang digunakan Geertz kali ini adalah "makna" (interpretasi) yang diperolehnya melalui deskripsi (dan abstraksi). Tidak ada anthropolog yang lebih bersemangat ketimbang Geertz dalam memberikan deskiripsi yang "mendalam" bahkan kadang sangat puitis. Berikut ini adalah deskripsinya tentang Bali yang mulai dilelitinya pada pertengahan 1950-an dan baru dibukukan pada 1980 dengan tajuk Negara: The Theatre State in Ninetenth-Century Bali.

Pertama-tama Geertz menawarkan model penulisan sejarah lain yang agak berbeda dengan aliran sejarah konvensional, meskipun dia kembali menegaskan diri bukan seorang sejarawan. "Aku ini anthropolog”. Sejarah, katanya, tidak harus ditulis sebagai peristiwa-peristiwa atau cerita-cerita seperti tentang Kertanegara yang pemabuk biasa atau pertapa yang kesurupan, atau apakah Syailendra itu wangsa Sumatra yang memerintah Jawa atau wangsa Jawa yang memerintah Sumatera. Geertz tidak menyukai gaya CC. Berg yang memahami sejarah adalah sebagai deretan cerita mengenai raja-raja berikut perwatakannya. Kadang- kadang sejarah yang demikian tidak ada gunanya. Maka, agar tidak tergoda dengan sejarah yang demikian, katanya, peristiwa- peristiwa itu perlu direkontruksi dengan urutan-urutan waktu dengan menyisipkan abstraksi-abstraksi dalam waktu waktu yang kosong ${ }^{13}$.

Geertz mengatakan, pemahaman mengenai karakteristik tokok-tokoh dalam sejarah membantu kita untuk membuat semacam abstraksi. Dia menyusun sejarah awal 
mula Bali yang dikalahkan oleh orang Jawa. Bali lalu dipimpin oleh seorang raja setengah dewa karena dia adalah pendeta dari Jawa yang menikah dengan bidadari. Dan Seterusnya. Tidak ada yang perlu disoal dari mitos, mungkin demikian Geertz. Justru, melalui mitos-mitos itu dia mendapatkan banyak makna baru mengenai orang Bali.

Bali kata Geertz adalah "negara” sendiri yang perlu dibedakan dari yang lain seperti Jawa. Dia berbeda dengan Indonesianis terkemuka pertama Sir Thomas Rafless yang menganggap bahwa kebudayaan Bali adalah kebudayaan Hindu-Jawa yang masih utuh dan belum terpengaruh oleh unsur-unsur modern. Bagaimanapun juga keterpencilan Bali yang sangat berbeda dengan Jawa menumbuhkan kebudayaan yang berbeda di sana.

Yang paling menarik dari tulisan Geertz mengenai Bali, bahkan dia memaparkannya dengan sangat puitis dengan nada mengiba adalah ketika menuliskan kembali kisah tetang matinya seorang raja Bali pada 1847. Tersebutlah bawa, raja itu dibakar dalam tumpukan unggun, lalu ketiga selirnya yang berpakaian cerah menyeburkan diri kedalam kobaran api dengan penuh semangat. Dengan bantuan data dari Weber mengenai sistem kasta Hindu, Geertz bercerita bahwa ratusan orang dari kasta yang lebih rendah menyaksikan itu dan menganggapnya sebagai hal-hal biasa yang diyakini benar. Tiga selir yang menyeburkan diri ke dalam api itu akan bersama raja di Sorga sana. Agama di Bali melalui para actor keagamaan dan pemerintahannya telah menandai tradisi ini. Dia meneruskan, kedatangan Inggris dan tidak diragukan lagi Belanda telah "berjasa" melenyapkan tradisi yang biadab ini.

Mengamati para pria Bali yang menguasasi wanita-wanitanya, Geertz mengatakan, mereka adalah kekasih, pengintrik, dan penanda tempat. Mereka berjalan melintasi realitas, membangun keraton-keraton, menulis perjanjian-perjanjian, menarik pajak- pajak, melakukan pernikaahan, membunuh saingan, menyucikan pura, menyalakan unggun, menyelenggarakan pesta, meniru para dewa, dan mengejar tujuan-tujuan yang mereka bayangkan dengan sarana yang mereka miliki. Drama dalam "negara teater" itu, kata Geertz dengan nada peyoratif, bukanlah ilusi atau pun dusta, bukan sulap atau hayalan, tetapi begitulah adanya. 


\section{CATATAN AKHIR}

Di Jawa dan Bali, misi Geertz yang pertama sebagai anthropolog adalah untuk melakukan etnografi - untuk menyiapkan deskripsi yang mendetail dan sistemetis tentang masyarakat-masyarakat non-Barat, khususnya memperlihatkan bagaimana aspek-aspek kehidupan yang berbeda bercampur dalam suatu kesatuan budaya. Silahkan pembaca menyimak dan menyimpulkan Geertz sebanyak banyaknya. Penulis menyimpulkan dua hal penting dari Gerrtz. Pertama, Geertz menganggap agama semata-mata sebagai fakta budaya, berupa ritual-ritual yang nampak lalu dimaknainya sendiri dengan caranya. Kali ini Geertzadalah seorang anthropolog "murni”( dan pastilah bukan agamawan). Kedua, "interpertasi budaya" yang ditonjolkan Geertz masih memosikan budaya Barat sebagai budaya unggul, budaya modern, budaya percontohan. Ini tidak menarik. Lihat bagaimana Geertz dalam Interpretation of Cultures (1973) mengecam seorang Antropolog Struktural Perancis Claude Levis- Stauss sebagai ilmuwan "cengeng” karena berani-beraninya mencoba masuk "ruang paling dalam" dari budaya "orang asing" yang ingin distandarkan oleh modernisasi Barat.

Sebagai penutup, telah disinggung di awal tulisan ini bahwa trikotomi abangan, santri, dan priyayi telah menjadikan Geertz terkenal di Indonesia. Namun banyak yang problematik jika trikotomi itu masih dipakai. Jika Geertz memakai nama santri sebagai pedagang Islam yang kearab-araban, kini penyebutan santri ditujukan untuk kaum pesantren yang dekat dengan tradisi Jawa dan hampir mirip dengan tipe abangan Geertz. Sementara kelompok yang dulu disebut Geertz sebagai santri kini telah menjadi orang Islam biasa, kadang disebut sebagai pembaharu, kadang bahkan terlalu radikal mengkontektualisasikan kearabannya di Indonesia. Lalu dimanakah abangan sekarang?

Istilah priyayi sepertinya sengaja dimunculkan Geertz untuk menunjukkan bahwa westernisasi sesungguhnya difasilitasi oleh kelompok ini: kelompok elit budaya yang sekaligus elit pemerintahan, dan bukan oleh para pendatang dari Eropa. Baiklah, akan tetapi sekarang ini siapa priyayi di antara kita?

Geertz sendiri mengakui ada beberapa hal yang (di) sembrono(kan) dari trikotominya itu. Dalam After The Fact Geertz sempat menggerutu ketika, katanya, 
buku The Religion of Java oleh penerbit di Indonesia disuguhkan kepada pembaca yang telah "terprogram”. "Jangan hanya santri, abangan dan priyayi-nya yang anda lihat; jangan sektarian; jangan hanya lihat permukaannya saja. Gagasan saya adalah The Religion of Java, tidak kurang dari itu," mungkin begitu kata Geertz.

\section{DAFTAR PUSTAKA}

Karya-karya Geertz: Available Light: Anthropological Reflections on Philosophical Topics (2000), After the Fact: Two Countries, Four Decades, One Anthropologist (1995), Works and Lives: The Anthropologist As Author (1988),

Local Knowledge: Further Essays in Interpretive Anthropology (1983), Negara: The Theatre

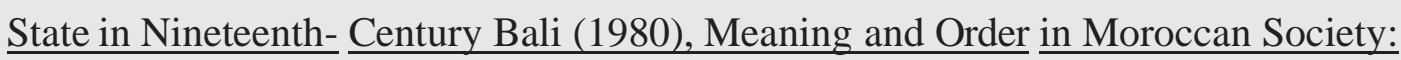
Three Essays in Cultural Analysis (1979), The Religion

of Java (1976), The Interpretation of Cultures: Selected Essays (1973), Islam Observed: $\underline{\text { Religious Development }}$

in Morocco and Indonesia (1971), Agricultural Involution: The Process of Ecological Change in Indonesia (1963) 